\title{
ANALISIS KESTABILAN LERENG DENGAN METODE KESETIMBANGAN BATAS PADA LERENG HIGH WALL PIT 1 UTARA TAMBANG BANKO BARAT MENGGUNAKAN SOFTWARE GEOSTUDIO SLOPE/W 2018 DI PT BUKIT ASAM, Tbk. TANJUNG ENIM, SUMATERA SELATAN
}

\author{
SLOPE STABILITY ANALYSIS WITH BOUNDARY EQUILIBRIUM METHODS ON THE HIGH \\ WALL PIT NORTH 1 WEST BANKO MINE USES 2018 GEOSTUDIO SLOPE/W SOFTWARE AT \\ PT BUKIT ASAM, TBK. TANJUNG ENIM, SOUTH SUMATRA
}

\author{
Sepriadi ${ }^{1)}$, Andre Muhid Prastowo ${ }^{2)}$ \\ ${ }^{1,2)}$ Program Studi Teknik Pertambangan Batubara Politeknik Akamigas Palembang, 30257, Indonesia \\ Corresponding Author E-mail: sepri@pap.ac.id
}

\begin{abstract}
Before conducting mining activities, to be able to facilitate the production process an activity is carried out, namely to design a slope design to ensure security for workers in the mining front area to minimize the occurrence of work accidents, especially in slope areas that are closely related to landslides. PT Bukit Asam, Tbk. using the standard slope safety factor according to the Bowles (1984) classification with FK> 1,25 which means the slope is stable. The process of making the mine slope design plan is assisted by using the Geosudio Slope/W 2018 software by using the boundary balance method. In making the slope design, the height of the bench, the width of the berm, and the angles of each single slope and overall slope must be considered, the higher and steeper the slope the smaller the FK value will be. In determining the value of the slope safety factor, there are several other factors that also affect the FK slope value, namely the input value in the form of unit weight, cohesion, and inner shear angle. The results of the calculation of slope safety factor using the Gesotudio Slope/W 2018 software obtained FK values of 2,096 which means the slopes are stable at the siatuasi in February 2019. Slope design is made to obtain the optimum FK value so that the excavation material can be maximized taking into account safety and regulatory factors which applies to the design of the slope to be made. The results obtained are the distance of the crest to the river $50,4 \mathrm{~m}$ with the overall slope angle of $28,25^{\circ}$ and the FK value of 1,259 which indicates that the slope is in a stable condition.

Keywords: slope design, safety factor, Geostudio Slope/W 2018 software
\end{abstract}

Abstrak: Sebelum melakukan kegiatan penambangan, untuk dapat memudahkan dalam proses produksi dilakukan suatu kegiatan, yaitu membuat rancangan desain lereng agar terjaminnya keamanan bagi para pekerja di area front kerja penambangan guna meminimalisir terjadinya kecelakaan kerja terutama pada daerah lereng yang erat kaitannya dengan kelongsoran. PT Bukit Asam, Tbk. menggunakan standar faktor keamanan lereng menurut klasifikasi Bowles (1984) dengan $F K>1,25$ yang berarti lereng dalam keadaan stabil. Proses Pembuatan rencana desain lereng tambang ini dibantu dengan menggunakan software Geosudio Slope/W 2018 dengan menggukan metode kesetimbangan batas. Dalam pembuatan desain lereng harus diperhatikan tinggi bench, lebar berm, dan sudut tiap single slope maupun overall slope, semakin tinggi dan terjal suatu lereng maka nilai FK yang didapatkan akan semakin kecil begitu pula sebaliknya. Dalam menentukan nilai faktor keamanan lereng, terdapat beberapa faktor lainnya yang juga mempengaruhi nilai FK lereng, yaitu nilai masukan berupa unit weight, kohesi, dan sudut geser dalam. Hasil perhitungan nilai faktor keamanan lereng dengan menggunakan software Gesotudio Slope/W 2018 didapatkan nilai FK sebesar 2,096 yang berarti lereng dalam keadaan stabil pada siatuasi bulan Februari 2019. Desain Lereng dibuat untuk mendapatkan nilai FK optimum agar bahan galian dapat dimaksimalkan dengan memperhatikan faktor kemanan dan peraturan yang berlaku terhadap desain lereng yang akan dibuat. Hasil yang didapatkan yaitu jarak crest terhadap sungai 50,4 m dengan sudut overall slope 28,25 dan nilai FK sebesar 1,259 yang menunjukkan bahwa lereng tersebut dalam keadaam stabil.

Kata Kunci : desain lereng, faktor keamanan, software Geostudio Slope/W 2018

\section{PENDAHULUAN}

\subsection{Latar Belakang}

Masalah kemantapan lereng pada batuan merupakan suatu hal yang menarik, karena sifat-sifat dan perilakunya yang berbeda dengan kestabilan lerang pada tanah. Kestabilan lereng pada batuan lebih ditentukan oleh adanya bidang-bidang lemah yang disebut dengan bidang diskontinuitas, tidak 
demikian halnya dengan lereng-lereng pada tanah.

Adanya kegiatan penambangan, seperti penggalian pada suatu lereng akan menyebabkan terjadinya perubahan besarnya gaya-gaya pada lereng tersebut yang mengakibatkan terganggunya kestabilan lereng dan pada akhirnya dapat menyebabkan lereng tersebut longsor. Dalam merancang suatu tambang terbuka dilakukan suatu analisis terhadap kestabilan lereng yang terjadi karena proses penimbunan maupun penggalian sehingga dapat memberikan kontribusi rancangan yang aman dan ekonomis.

Stabilitas dari lereng individual biasanya menjadi masalah yang membutuhkan perhatian yang lebih bagi kelangsungan operasi penambangan setiap harinya. Longsornya lereng pada suatu jenjang, dimana terdapat jalan angkut utama atau berdekatan dengan batas properti atau instalasi penting, dapat menyebabkan bermacam gangguan pada program penambangan.

Walaupun longsoran yang terjadi relatif kecil, dengan tanda-tanda yang tidak begitu terlihat, tetap saja dapat membahayakan jiwa dan merusak peralatan yang ada. Faktor keamanan didefinisikan sebagai perbandingan antara gaya yang menahan dengan gaya yang menggerakkan. Penelitian kali ini dilakukan di pit 1 utara yang merupakan daerah yang dijadikan sebagai tempat penelitian juga dihadapkan dengan masalah lain, yaitu berbatasan sungai. Hal tersebut yang mendasari Penulis untuk melakukan penelitian dengan cara membuat desain lereng dengan FK yang aman tetapi tetap memperhatikan peraturan yang berlaku untuk pembuatan desain yang berbatasan dengan sungai. Pembuatan desain lereng ini dibantu menggunakan software Geostudio Slope/W 2018.

\subsection{Rumusan Masalah}

Penelitian ini dilakukan karena adanya permasalahan teknis untuk kemantapan lereng yang ada pada pit penambangan. Permasalahan tersebut terutama dalam batas aman penambangan pada pit 1 Utara yang sekarang yang berdekatan dengan sungai

\subsection{Batasan Masalah}

Dalam penelitian ini Penulis akan membahas tentang stabilitas lereng tambang terbuka di PT Bukit Asam, Tbk. pembatasan masalah yang akan diambil Penulis antara lain:

1. Lokasi penelitian berada pada Pit 1 Utara Tambang Banko Barat Daerah pengamatan high wall, Tanjung Enim, Sumatera Selatan.

2. Analisis kestabilan lereng dilakukan menggunakan metode kesetimbangan batas dengan pendekatan MorgernsternPrice.

3. Perhitungan faktor keamanan lereng overall slope.

4. Faktor keamanan lereng optimasi $\geq 1,25$ (menurut Bowles, 1984).

5. Muka airtanah diasumsikan 10 meter di bawah permukaan.

\subsection{Tujuan Penelitian}

Tujuan dari analisis kestabilan lereng tambang terbuka ini sebagai berikut :

1. Menentukan FK lereng eksisting sisi high wall.

2. Memberikan rekomendasi rancangan desain lereng penambangan daerah penelitian Pit 1 Utara Banko Barat.

3. Mendapatkan desain lereng optimum dengan nilai faktor keamanan lereng tambang $\geq 1,25$ (Bowles, 1984).

\subsection{Manfaat Penelitian}

Manfaat penelitian terkait dengan analisis kestabilan lereng pada tambang terbuka, yaitu:

1. Dapat mengetahui tingkat keamanan lereng eksisting sisi high wall.

2. Dapat menjadi bahan pertimbangan perusahaan dalam memberikan rekomendasi Rancangan Kerja Anggaran Perusahaan (RKAP) terkait operasi penambangan di Pit 1 Utara Tambang Banko Barat.

3. Dapat mengetahui tingkat keamanan lereng tambang dan melakukan pendesainan ulang jika FK yang didapat tidak mencapai kestabilan yang 
diharapkan perusahaan dan berdasarkan klasifikasi Bowles (1984).

\section{TEORI DASAR}

\subsection{Kestabilan Lereng}

Kestabilan dari suatu jenjang individual dikontrol oleh kondisi geologi daerah setempat, bentuk keseluruhan lereng pada daerah tersebut, kondisi air tanah setempat, dan juga oleh teknik penggalian yang digunakan dalam pembuatan lereng. Faktor pengontrol ini jelas sangat berbeda untuk situasi penambangan yang berbeda dan sangat penting untuk memberikan aturan yang umum untuk menentukan seberapa tinggi atau seberapa landai suatu lereng untuk memastikan lereng itu akan stabil.

Apabila kestabilan dari suatu jenjang dalam operasi penambangan meragukan, maka kestabilannya harus dinilai berdasarkan dari struktur geologi, kondisi air tanah dan faktor pengontrol lainnya yang terjadi pada suatu lereng. Kestabilan lereng pada batuan dipengaruhi oleh geometri lereng, struktur batuan, sifat fisik dan mekanik batuan serta gaya-gaya luar yang bekerja pada lereng tersebut. Suatu cara yang umum untuk menyatakan kestabilan suatu lereng batuan adalah dengan faktor keamanan. Faktor ini merupakan perbandingan antara gaya penahan yang membuat lereng tetap stabil, dengan gaya penggerak yang menyebabkan terjadinya longsor. Secara matematis faktor kestabilan lereng dinyatakan sebagai berikut :

\section{Dimana :}

$$
\mathrm{F}=\mathrm{R} / \mathrm{F}_{\mathrm{p}}
$$

$$
\begin{aligned}
\mathrm{F}= & \text { faktor kestabilan lereng } \\
\mathrm{R}= & \text { gaya penahan, berupa resultan } \\
& \text { gaya-gaya yang membuat lereng } \\
& \text { tetap stabil } \\
\mathrm{F}_{\mathrm{p}}= & \text { gaya penggerak, berupa resultan } \\
& \text { gaya-gaya yang menyebabkan } \\
& \text { lereng longsor. }
\end{aligned}
$$

\subsection{Lereng}

Lereng adalah permukaan bumi yang membentuk sudut kemiringan tertentu dengan bidang horizontal. Lereng dapat terbentuk secara alami maupun buatan manusia. Lereng yang terbentuk secara alami misalnya: lereng bukit dan tebing sungai, sedangkan lereng buatan manusia, antara lain: galian dan timbunan untuk membuat bendungan, tanggul dan kanal sungai serta dinding tambang terbuka (Arief, 2007). Pada sebuah galian tambang terdiri dari tiga bagian yaitu : high wall, low wall, dan side wall.

a) High wall adalah permukaan kerja tambang terbuka yaitu khususnya tambang batubara terbuka, permukaan atau lereng dibagian yang lebih tinggi dari suatu kontur tambang terbuka. Dapat juga diartikan sebagai sisi bukaan tanah/batuan, sisi tanah buangan arah tegak lurus terhadap sisi buangan dan arah kemajuan tambang (high wall)

b) Low wall adalah sisi bukaan tanah penutup batubara atau bahan galian tambang lainnya pada tambang terbuka. Low wall dapat ditentukan (searah) berdasarkan bedding dip suatu permukaan tanah.

c) Side wall adalah dinding pada area sisi samping suatu lubang bukaan tambang. Umumnya side wall tegak lurus terhadap low wall dan high wall pada area pit.

Lereng tersusun atas batuan yang memiliki komposisi tertentu yang termuat didalamnya. Komposisi penyusun batuan dapat berupa mineral yang merupakan material padat anorganik yang terbentuk secara alamiah atau organik yang sudah mati. Batuan adalah material yang membentuk kulit bumi termasuk fluida yang berada di dalamnya (seperti air, minyak, dan lain-lain). Batuan penyusun lereng dapat mengalami perubahan sebagai pengaruh dari kondisi alam yang dinamis salah satu diantaranya adalah iklim.

\subsection{Faktor-faktor yang Mempengaruhi Kestabilan Lereng}

Umumnya stabil atau tidaknya suatu lereng tergantung dari beberapa faktor, antara lain :

a. Geometri lereng

Kemiringan dan tinggi suatu lereng sangat mempengaruhi kestabilannya. Semakin besar kemiringan dan ketinggian suatu lereng, maka kestabilan semakin berkurang. 
Geometri lereng yang dapat mempengaruhi kestabilan lereng meliputi tinggi lereng, kemiringan lereng dan lebar berm (b), baik itu lereng tunggal (single slope) maupun lereng keseluruhan (overall slope). Suatu lereng disebut lereng tunggal (single slope) jika dibentuk oleh satu jenjang saja dan disebut keseluruhan (overall slope) jika dibentuk oleh beberapa jenjang.

b. Struktur batuan

Strukutur batuan yang sangat mempengaruhi kestabilan lereng adalah bidang-bidang sesar, perlapisan dan rekahan. Struktur batuan tersebut merupakan bidangbidang lemah (diskontinuitas) dan sekaligus sebagai tempat merembesnya air, sehingga batuan lebih mudah longsor.

c. Sifat fisik dan mekanik batuan

Sifat fisik batuan yang mempengaruhi kestabilan lereng adalah : bobot isi (density), porositas dan kandungan air. Sedangkan sifat mekanik batuan antara lain kuat tekan, kuat tarik, kuat geser dan juga sudut geser dalam batuan.

Kuat geser batuan dapat dinyatakan sebagai berikut :

dimana :

$$
\tau=\mathrm{C}+(\sigma-\mu) \tan \theta
$$

$$
\begin{aligned}
\tau & =\text { kuat geser batuan }\left(\mathrm{ton} / \mathrm{m}^{2}\right) \\
\mathrm{C} & =\text { kohesi }\left(\operatorname{ton} / \mathrm{m}^{2}\right) \\
\sigma & = \\
\theta & \text { tegangan normal }\left(\mathrm{ton} / \mathrm{m}^{2}\right) \\
= & \text { sudut geser dalam (angle of internal } \\
& \text { friction) }\left({ }^{\circ}\right)
\end{aligned}
$$

Untuk mengetahui nilai kohesi dan sudut geser dalam, dinyatakan dalam persamaan berikut :

$$
\begin{gathered}
\tau=\sigma^{\prime} \tan \phi+\mathrm{c} \\
\tau=\mathrm{c}+\tau^{\prime} \tan \phi \\
\tau^{\prime}=(\sigma-\mathrm{u})
\end{gathered}
$$

maka didapatkan Persamaan :

\section{Dimana :}

$$
\tau=(\sigma-\mathrm{u}) \tan \phi+\mathrm{c}
$$

$$
\begin{aligned}
\tau_{\mathrm{nt}} & =\text { tegangan geser }\left(\mathrm{kN} / \mathrm{m}^{2}\right) \\
\sigma_{\mathrm{n}} & =\text { tegangan normal }\left(\mathrm{kN} / \mathrm{m}^{2}\right) \\
\phi & =\text { sudut geser dalam }\left({ }^{\mathrm{o}}\right) \\
\mathrm{c} & =\text { kohesi }\left(\mathrm{kN} / \mathrm{m}^{2}\right)
\end{aligned}
$$

Gaya-gaya dari luar yang dapat mempengaruhi (mengurangi) kestabilan suatu lereng adalah :

1. Getaran yang diakibatkan oleh gempa, peledakan dan pemakaian alat-alat mekanis yang berat didekat lereng

2. Pemotongan dasar (toe) lereng

3. Penebangan pohon-pohon pelindung lereng

\subsection{Jenis-jenis Longsoran}

Ada beberapa jenis longsoran yang umum dijumpai pada massa batuan ditambang terbuka, yaitu :

a. Longsoran bidang (plane failure)

Longsoran jenis ini (Gambar 2.3) akan terjadi jika kondisi di bawah ini terpenuhi:

1. Jurus (strike) bidang luncur mendekati pararel terhadap jurus bidang permukaan lereng (perbedaan maksimum $20^{\circ}$ ).

2. Kemiringan bidang luncur ( $\psi p)$ harus lebih kecil daripada kemiringan bidang permukaan lereng $(\psi \mathrm{f})$.

3. Kemiringan bidang luncur ( $\psi p)$ lebih besar daripada sudut geser dalam $(\varphi)$.

4. Terdapat bidang bebas yang merupakan batas lateral dari massa batuan atau tanah yang longsor.

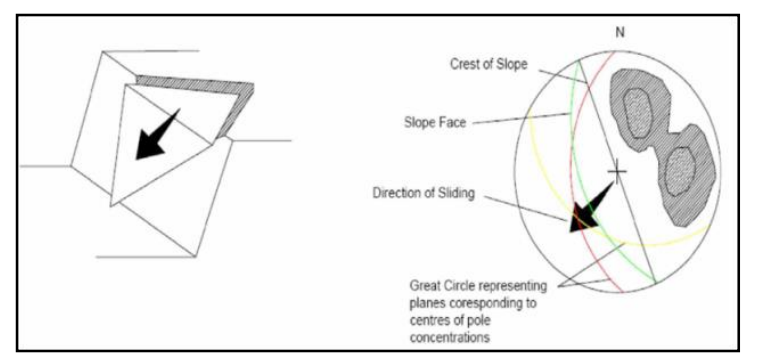

Sumber : Hoek dan Bray, 1981

Gambar 2.1 Longsoran Bidang

b. Longsoran baji (wedge failure)

Longsoran baji terjadi bila terdapat dua bidang lemah atau lebih berpotongan sedemikian rupa sehingga membentuk baji terhadap lereng. Longsoran baji ini dapat dibedakan menjadi dua tipe longsoran yaitu, longsoran tunggal (single sliding) dan longsoran ganda (double sliding). Untuk longsoran tunggal, luncuran terjadi pada salah satu bidang, sedangkan untuk 
longsoran ganda luncuran terjadi pada perpotongan kedua bidang. Longsoran baji tersebut akan terjadi bila memenuhi syarat sebagai berikut :

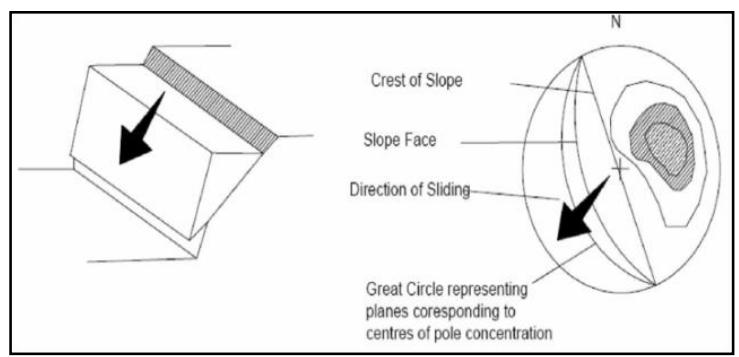

Sumber : Hoek dan Bray, 1981

\section{Gambar 2.2 Longsoran Baji}

1. Kemiringan lereng lebih besar daripada kemiringan garis potong kedua bidang lemah $(\psi f i>\psi i)$.

2. Sudut garis potong kedua bidang lemah lebih besar daripada sudut geser dalamnya $(\psi f i>\varphi)$

c. Longsoran guling (toppling failure)

Longsoran guling umumnya terjadi pada lereng yang terjal dan pada batuan yang keras dimana struktur bidang lemahnya berbentuk kolom. Longsoran jenis ini terjadi apabila bidang-bidang lemah yang ada berlawanan dengan kemiringan lereng. Longsoran guling pada blok fleksibel terjadi jika :

1. $\beta>900+\varphi-\alpha$, di mana $\beta=$ kemiringan bidang lemah, $\varphi=$ sudut geser dalam dan $\alpha=$ kemiringan lereng.

2. Perbedaan maksimal jurus (strike) dari kekar (joint) dengan jurus lereng (slope) adalah 300 .

d. Longsoran busur (circular failure)

Longsoran busur umumnya terjadi pada material yang bersifat lepas (loose material) seperti material tanah. Sesuai dengan namanya, bidang longsorannya berbentuk busur (Gambar 2.6). Batuan hancur yang terdapat pada suatu daerah penimbunan dengan dimensi besar akan cenderung longsor dalam bentuk busur lingkaran (Hoek dan Bray, 1981). Pada longsoran busur yang terjadi pada daerah timbunan, factor struktur geologi tidak terlalu berpengaruh pada kestabilan lereng timbunan.

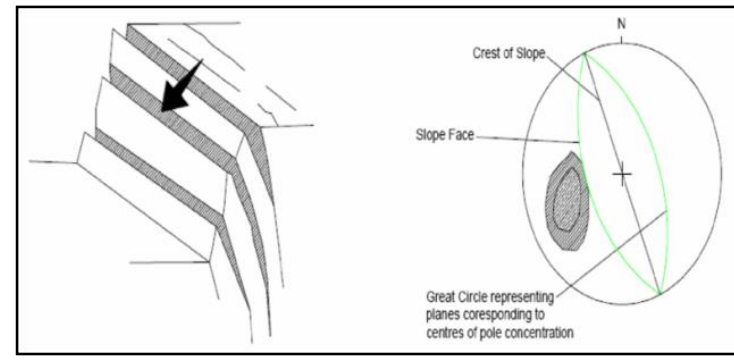

Sumber : Hoek dan Bray, 1981

Gambar 2.3 Longsoran Guling

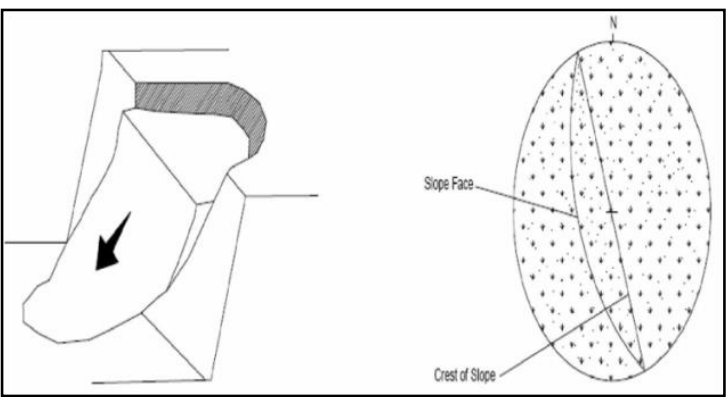

Sumber : Hoek dan Bray, 1981

Gambar 2.4 Longsoran Busur

\subsection{Nilai Safety Factor (SF) Terhadap Kestabilan Lereng \\ Kelongsoran suatu lereng} penambangan umumnya terjadi melalui sutu bidang tertentu yang disebut dengan bidang gelincir (slip surface). Kestabilan lereng tergantung pada gaya pengerak dan gaya penahan yang bekerja pada bidang gelincir tersebut. Gaya penahan (resisting force) adalah gaya yang menahan agar tidak terjadi kelongsoran, sedangkan gaya penggerak (driving force) adalah gaya yang menyebabkan terjadinya kelongsoran. Perbandingan antara gaya-gaya penahan terhadap gaya-gaya penggerak tanah inilah yang disebut dengan faktor keamanan lereng (FK).

Tabel 2.1 Nilai Faktor Keamanan untuk Perencanaan Lereng

\begin{tabular}{|l|l|}
\hline Nilai FK & Keadaan lereng \\
\hline$<1,0$ & Tidak mantap \\
\hline $1,0-1,2$ & Kemantapan diragukan \\
\hline $1,3-1,4$ & $\begin{array}{l}\text { Memuaskan untuk pemotongan } \\
\text { dan penimbunan }\end{array}$ \\
\hline $1,4-1,7$ & Mantap untuk bendungan \\
\hline
\end{tabular}

Sumber : Sosrasardono dalam Made Astawa Rai, 1993 
Tabel 2.2 Hubungan Nilai FK dan Kemungkinan Kelongsoran Lereng

\begin{tabular}{|l|l|}
\hline Nilai FK & Kemungkinan Longsor \\
\hline$<1,07$ & $\begin{array}{l}\text { Kelongsoran biasa terjadi } \\
\text { (lereng labil) }\end{array}$ \\
\hline $1,07<\mathrm{FK}<1,25$ & $\begin{array}{l}\text { Kelongsoran pernah terjadi } \\
\text { (lereng kritis) }\end{array}$ \\
\hline$>1,25$ & $\begin{array}{l}\text { Kelongsoran jarang terjadi } \\
\text { (lereng relatif stabil) }\end{array}$ \\
\hline
\end{tabular}

Sumber : Bowles, 1984

Tabel 2.3 Kisaran Faktor Keamanan

\begin{tabular}{|l|l|}
\hline Faktor Keamanan & Kerentanan Gerakan Tanah \\
\hline FK $<1,2$ & $\begin{array}{l}\text { Tinggi, gerakan tanah sering } \\
\text { terjadi }\end{array}$ \\
\hline $1,2<$ FK $<1,7$ & $\begin{array}{l}\text { Menengah, gerakan tanah } \\
\text { dapat terjadi }\end{array}$ \\
\hline $1,7<$ FK $<2,0$ & $\begin{array}{l}\text { Rendah, gerakan tanah dapat } \\
\text { terjadi }\end{array}$ \\
\hline FK $>2,0$ & $\begin{array}{l}\text { Sangat Rendah, gerakan tanah } \\
\text { sangat jarang terjadi }\end{array}$ \\
\hline
\end{tabular}

Sumber : Ward, 1976

\subsection{Massa Batuan, Struktur Batuan dan Bidang Diskontinu}

\subsubsection{Massa Batuan}

Massa batuan merupakan volume batuan yang terdiri dari material batuan berupa mineral, tekstur dan komposisi dan juga terdiri dari bidang-bidang diskontinu, membentuk suatu material dan saling berhubungan dengan semua elemen sebagai suatu kesatuan. Kekuatan massa batuan sangat dipengaruhi oleh frekuensi bidang-bidang diskontinu yang terbentuk. Oleh sebab itu, massa batuan akan mempunyai kekuatan yang lebih kecil bila dibandingkan dengan batuan utuh. Menurut Hoek dan Bray (1981), massa batuan adalah batuan insitu yang dijadikan diskontinu oleh sistem struktur seperti joint, sesar dan bidang perlapisan.

\subsubsection{Struktur Batuan}

Struktur batuan adalah gambaran tentang kenampakan atau keadaan batuan, termasuk di dalamnya bentuk atau kedudukannya. Berdasarkan keterjadiannya, struktur batuan dapat dikelompokkan menjadi:

1. Struktur primer merupakan struktur yang terjadi pada saat proses pembentukan batuan. Misalnya : bidang perlapisan silang (cross bedding) pada batuan sedimen atau kekar akibat pendinginan (cooling joint) pada batuan beku.

2. Struktur skunder merupakan struktur yang terjadi kemudian setelah batuan terbentuk akibat adanya proses deformasi atau tektonik. Misalnya : lipatan (fold), patahan (fault) dan kekar (joint). Bidang diskontinu dapat ditemukan pada struktur primer maupun struktur sekunder.

\subsubsection{Bidang Diskontinu}

Secara umum bidang diskontinu merupakan bidang yang memisahkan massa batuan menjadi bagian yang terpisah. Menurut Priest (1993), pengertian bidang diskontinu adalah setiap bidang lemah yang terjadi pada bagian yang memiliki kuat tarik paling lemah dalam batuan. Menurut Gabrielsen (1990), keterjadian bidang diskontinu tidak terlepas dari masalah perubahaan stress (tegangan), temperatur, strain (regangan), mineralisasi dan rekristalisasi yang terjadi pada massa batuan dalam waktu yang panjang.

Beberapa jenis bidang diskontinu yang digolongkan berdasarkan ukuran dan komposisinya sebagai berikut :

1. Fault (patahan)

2. Joint (kekar)

3. Bedding (bidang pelapisan)

4. Fracture dan crack

5. Fissure

Dari semua jenis bidang diskontinu yang ada, joint adalah yang paling sering menjadi pertimbangan. Hal ini disebabkan joint merupakan bidang diskontinu yang telah pecah dan terbuka, sehingga bidang joint merupakan bidang yang lemah. Selain itu joint sering bahkan hampir selalu ada pada suatu massa batuan. Oleh sebab itu, dalam pertimbangan geoteknik, seringkali joint lebih menjadi perhatian dibandingkan jenis bidang diskontinu lainnya.

Dalam analisis bidang diskontinu terdapat beberapa istilah yang biasa dipakai secara umum. Berikut ini akan dibahas 
beberapa poin yang berkaitan dengan bidang diskontinu.

\section{Joint set}

Joint set adalah sejumlah joint yang memiliki orientasi yang relatif sama, atau sekelompok joint yang paralel.

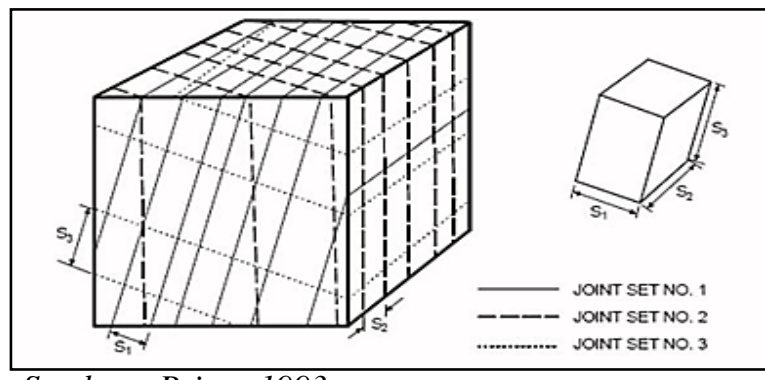

Sumber : Priest, 1993

Gambar 2.5 Diagram Blok dengan 3 Joint Set

Pada Gambar 2.5, tampak sebuah blok batuan yang memiliki tiga joint set, masing-masing joint set 1, 2 dan 3.

2. Spasi bidang diskontinu (joint spacing)

Menurut Priest (1993) ada tiga macam spasi bidang diskontinu. Ketiga macam joint spacing tersebut adalah spasi total (total spacing), spasi set (set/joint set spacing) dan spasi set normal (normal set spacing).

3. Orientasi bidang diskontinu (Joint Orientation)

Orientasi bidang diskontinu adalah kedudukan dari bidang diskontinu yang meliputi arah dan kemiringan bidang. Arah dan kemiringan dari bidang diskontinu biasanya dinyatakan dalam (Strike/Dip) atau (Dip Direction/Dip).

\subsection{Geo Slope Office}

Selain perhitungan manual, stabilitas lereng dapat juga dianalisis menggunakan software komputer. Ada beberapa macam software yang telah dikembangkan. Tapi untuk penelitian ini akan menggunakan software Geo slope Office. Geo Slope adalah suatu software yang membantu insinyur dalam menyelesaikan suatu permasalahan terutama yang berhubungan dengan tanah. Geo slope terdiri dari beberapa bagian sub program yang kesemuanya dapat diintegrasikan satu dengan yang lainnya jika dibutuhkan. Sub program Geo slope, yaitu:
a. Slope/W,
b. Seep/W,
c. $C \operatorname{tran} / W$,
d. Sigma/W,
e. Temp/W,
f. Quake/W, dan
g. Vadose/W.

\subsubsection{Geo Slope/W 2018}

Slope/W merupakan produk software yang menggunakan batas keseimbangan untuk menghitung faktor keamanan tanah dan lereng. Menganalisa stabilitas lereng, menggunakan batas keseimbangan, serta mempunyai kemampuan untuk menganalisis contoh tanah yang berbeda jenis dan tipe, longsor dan kondisi tekanan air pori dalam tanah yang berubah menggunakan bagian besar. Contoh tanah. Slope/ $W$ merupakan sub program dari Geo Slope yang dapat diintegrasikan dengan sub program lainnya, baik Vadose/W, Seep/W, Quake/W dan Sigma/W. Parameter masukan data analisa dapat ditentukan atau secara probabilitas. Beberapa permasalahan yang dapa diselesaikan dan kemampuan dari Slope/W :

1. Menghitung faktor keamanan lereng yang bertanah heterogen di atas tanah keras (bedrock), dengan lapisan lempung. Di ujung lereng (lembah) merupakan genangan air, air tanah mengalir sampai ujung lereng dan daerah retakan berkembang pada puncak akibat gaya tegangan pada lereng.

2. Slope/W dapat menghitung faktor keamanan dari lereng dengan beban luar dan perkuatan lereng dengan angker atau perkuatan dengan geo-textile

3. Kondisi tekanan air pori dalam tanah yang kompleks, kondisi air pori dapat dibedakan dalam beberapa cara, dapat semudah seperti garis piezometrik atau analisa elemen batas dari tekanan pori. Tekanan air pori pada tiap dasar potongan lereng ditemukan dari data titik cara interpolasi spline.

4. Menganalisa stabilitas dengan tekanan batas elemen. Memasukkan data tekanan 
lereng dari analisa batas stabilitas elemen Sigma/W ke Slope/W untuk mempermudah. Keuntungan lain yaitu dapat menghitung faktor keamanan tiap potongan, sebaik perhitungan faktor keamanan seluruh longsoran. Pada dasarnya Slope $W$ terdiri dari tiga bagian pengerjaan (langkah kerja), yaitu:

1. Define : Pendefinisian model.

2. Solve : Nilai dari hasil perhitungan, dengan menekan start

3. Contour : memperlihatkan gambaran hasil perhitungan

\subsubsection{Metode Morgenstern-Price}

Kestabilan suatu lereng secara matematis merupakan fungsi dari gaya yang mendorong untuk longsor atau driving force dan gaya yang menahan longsor resisting force (Cheng dan Lau, 2008). Kestabilan suatu lereng dinyatakan dalam safety factor (SF). Perhitungan safety factor suatu lereng dapat dilakukan dengan menggunakan berbagai metode. Metode yang umum digunakan untuk perhitungan SF antara lain Fellenius, Bishop's Simplified, Janbu's Simplified, Corps of Engineering, Lowe \& Karfiath, Spencer, Sarma, dan Morgenstern \& Price. Pada bidang gelincir melingkar metode perhitungan SF yang digunakan secara luas di seluruh dunia adalah Fellenius dan Bishop. Pada perhitungan SF untuk bidang gelincir yang tidak melingkar, maka metode yang sering digunakan adalah Janbu dan MorgensternPrice.

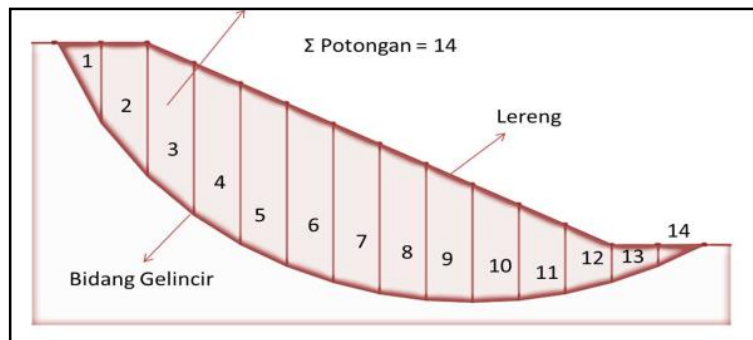

Sumber : Krahn, 2004

\section{Gambar 2.6 Pembagian Potongan pada Suatu Lereng dan Bidang Gelincir di Dalam Lereng}

Pada kali ini Penulis akan melakukan penelitian menggunakan metode Morgenstern-
Price. Metode perhitungan SF dilakukan dengan metode Morgenstern-Price. Pemilihan metode Morgenstern-Price dalam analisis dilakukan karena metode ini mempertimbangkan enam kriteria, yaitu keseimbangan momen, keseimbangan gaya, gaya normal antar potongan $(\mathrm{X})$, gaya geser antar potongan (E), inklinasi dari resultan $\mathrm{X} / \mathrm{E}$, dan hubungan antara X-E (Krahn, 2004).

Keunggulan lain dari digunakannya metode Morgenstern-Price untuk analisis stabilitas lereng menurut Krahn (2004) adalah variasi dari gaya antar potongan dapat dimodelkan. Perhitungan safety factor pada dasarnya adalah perhitungan jumlah gaya antar potongan pada model lereng yang dibuat. Lereng yang dibuat dibagi menjadi potonganpotongan kecil untuk memudahkan perhitungan (Gambar 2.6).

Metode Morgenstern-Price dapat digunakan dalam:

a. memperhitungkan gaya-gaya antar irisan

b. mengasumsikan gaya-gaya antar irisan adalah fungsi $\mathrm{f}(\mathrm{x})$ menghitung angka keamanan dengan keseimbangan momen dan keseimbangan gaya

\section{METODOLOGI PENELITIAN}

\subsection{Jenis Penelitian}

Jenis penelitian yang dilakukan adalah penelitian eksperimental. Penelitian eksperimental merupakan penelitian yang memanipulasi atau mengontrol situasi alamiah dengan cara membuat kondisi buatan (artificial condition).

\subsection{Waktu dan Tempat Penelitian}

Tempat yang akan dijadikan lokasi dalam penelitian ini berada di PT Bukit Asam, Tbk., Peneliti memfokuskan pada Tambang Banko Barat di Pit I Utara daerah pengamatan High Wall dalam waktu dua bulan.

\subsection{Metode Penelitian}

Masalah-masalah yang dibahas pada penelitian ini, dapat menggunakan beberapa metode penyelesaiannya sebagai berikut :

1. Studi literatur

Studi literatur dilakukan dengan mencari informasi serta teori yang berhubungan dengan kondisi jalan angkut 
berdasarkan referensi dari handbook, dan dari sumber referensi lainnya.

2. Observasi

Observasi lapangan ini dilakukan untuk mengamati kondisi nyata yang ada di lapangan dan mencari data secara langsung untuk memperoleh data-data yang diperlukan.

3. Pengambilan data

Pengambilan data tergantung dari jenis data yang dibutuhkan, yaitu

a. Data sekunder, antara lain : parameter sifat fisik dan mekanik batuan, peta situasi penambangan, dan kondisi geologi regional.

b. Data primer, antara lain : Dokumentasi daerah pengamatan

4. Pengumpulan data

Data yang akan diambil dan dikumpulkan kemudian diklasifikasikan berdasarkan jenis data sesuai dengan kebutuhan dan tujuan penelitian.

5. Pengolahan data

Data diolah berdasarkan dari data primer dan data sekunder, kemudian dimasukkan dalam sebuah tabel (tabulasi) dan data diolah berdasarkan kajian geoteknik dan berdasarkan tinjauan umum dari hal tentang kemantapan lereng tambang.

6. Analisis Hasil Pengolahan Data

Hasil dari data yang diperoleh di lapangan dan laboratorium kemudian dilakukan perhitungan dengan menggunakan rumusrumus yang diperoleh dari buku-buku literatur. Pada pengolahan data dibantu dengan menggunakan software Geostudio Slope W/2018.

7. Pembahasan

Melakukan pengkajian tentang apa yang telah dianalisis dari data yang sudah didapatkan melalui data primer dan data sekunder untuk dapat menyimpulkan dari apa yang telah dilaksanakan.

8. Penarikan Kesimpulan

Pengambilan kesimpulan adalah hasil dari pembahasan dari kegiatan yang telah dilakukan analisis sebelumnya. Kesimpulan menjadi point penting yang akan menjadi akhir penyelesaian dari penelitian yang dilakukan.

\section{HASIL DAN PEMBAHASAN \\ 4.1. Kondisi Lereng Penelitian}

Pada penelitian kali ini dilakukan pengamatan pada lokasi Pit 1 Utara Tambang Banko Barat pada sisi high wall. Analisis dilakukan untuk melakukan pengoptimaslisasian terhadap situasi bulan Februari 2019 guna mendapatkan FK optimum, yaitu 1,25 yang mengacu pada kriteria Bowles, 1984 (FK $\geq 1,25=$ Lereng dalam kondisi aman) dengan memperhatikan beberapa faktor dalam pembuatan desain lereng yang aman guna meminimalisir terjadinya hal yang tidak dinginkan seperti kecelakan kerja akibat kelongsoran lereng tambang. Acuan yang digunakan dalam pemodelan desain karena area penambangan berdekatan dengan aliran sungai, maka harus dibuat sesuai dengan aturan yang berlaku.

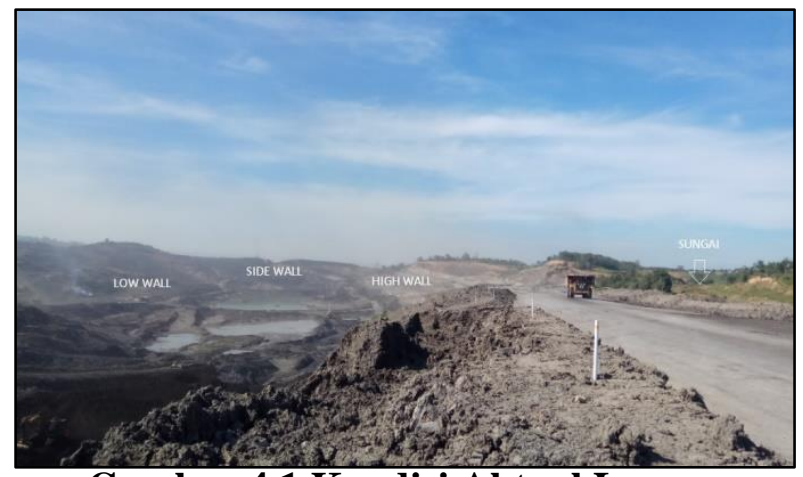

Gambar 4.1 Kondisi Aktual Lereng Pengamatan

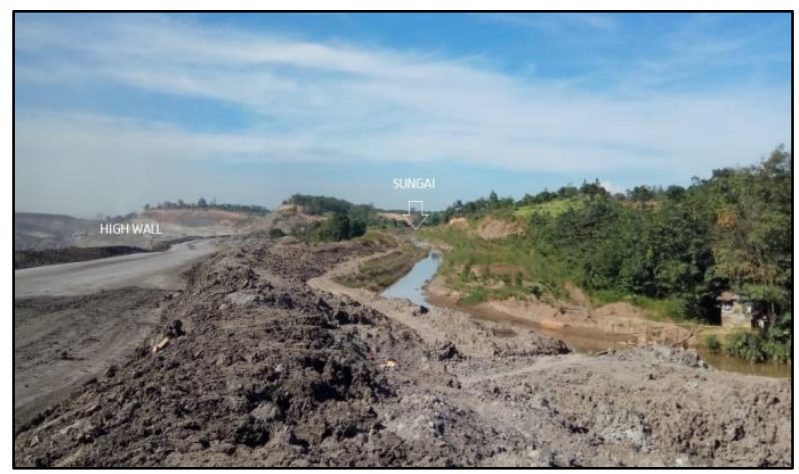

Gambar 4.2 Kondisi Aktual Aliran Sungai Daerah Pengamatan

Material yang ada pada Pit 1 Utara sisi high wall memiliki material, yaitu top soil 
pada bagian atas dan lapisan overburden, seam A1, interburden A1-A2, seam A2, dan interburden A2-B1 yang menerapkan metode penambangan strip mine yang menunjukkan kemajuan mengikuti arah perlapisan batubara (dip).

\subsection{Analisis Kestabilan Lereng Situasi Februari 2019}

Pada lereng situasi Februari 2019 diketahui jarak crest ke sungai sekitar 131,36 $\mathrm{m}$ dengan tinggi lereng keseluruhan dari toe sampai ke crest yaitu $41,5 \mathrm{~m}$ dengan elevasi toe berada pada $3,5 \mathrm{~m}$ dan elevasi crest berada pada $45 \mathrm{~m}$ diatas permukaan laut dengan sudut overall slope sebesar $25,75^{\circ}$. Didapatkan perhitungan faktor keamanan lereng menggunakan software Geostudio Slope/W 2018 sebesar $\mathrm{FK}=2,096$ yang berarti lereng dikategorikan dalam keadaan aman (FK > 1,25 = aman, menurut Bowles, 1984).

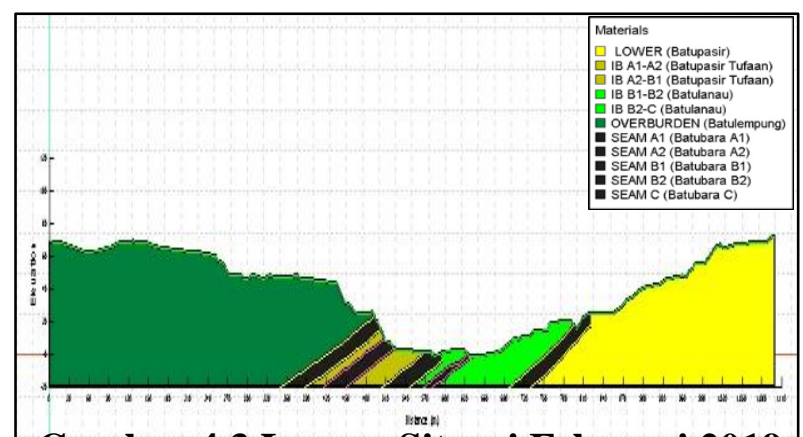

Gambar 4.3 Lereng Situasi Februari 2019 Sisi High Wall Boundary

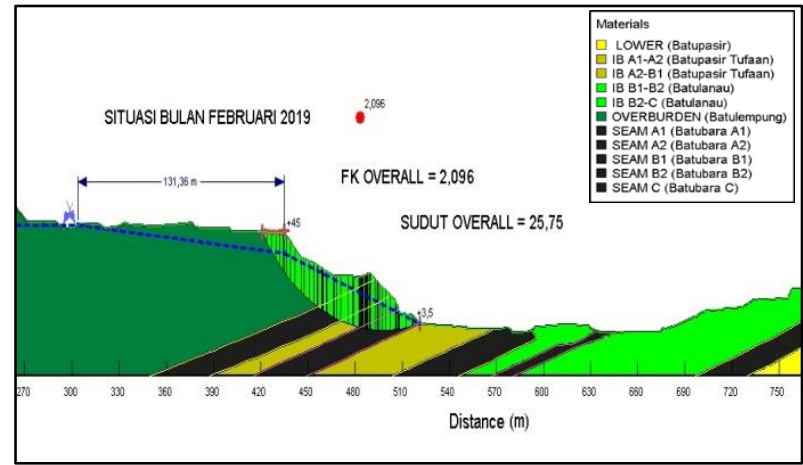

Gambar 4.4 Faktor Keamanan Lereng Situasi Februari 2019 Sisi High Wall

\subsection{Pemodelan Geoteknik}

Pemodelan Geoteknik ini berasal dari hasil pengeboran yang dilakukan pada saat eksplorasi. Penampang geoteknik berasal dari data topografi. Penampang geoteknik memuat peta situasi yang memuat tentang informasi nilai elevasi dan pengklasifikasian daerah yang telah dilakukan penggalian.

Lokasi penelitian pada Pit 1 Utara Banko Barat tidak diadakannya kegiatan peledakan karena daerah yang dekat dengan pemukiman penduduk agar tidak mengganggu penduduk sekitar akibat getaran dan debu yang dihasilkan oleh hasil peledakan. Maka besaran nilai faktor $g$ yang digunakan adalah 0,02 . Pada kondisi daerah penelitian tidak dilakukannya pengamatan secara pasti terhadap kondisi airtanah, hanya dilakukan dengan melihat kondisi muka airtanah yang ada tidak menunjukkan adanya aliran air di permukaan atau rembesan air pada lereng. Meskipun demikian, hal itu tidak dapat menunjukkan bahwa muka airtanah berada jauh di bawah permukaan dari pit tambang. Dalam melakukan pemodelan tinggi muka airtanah diasumsikan 10 meter di bawah permukaan tanah.

Pembuatan bench disesuaikan dengan kondisi lereng yang memenuhi persyaratan lereng dalam kondisi aman, semakin banyak bench yang dibuat maka semakin kecil FK yang dihasilkan. Penetuan besar nilai FK lereng juga ditentukan berdasarkan besaran sudut yang dibuat tiap single slope masingmasing bench. Semakin curam sudut lereng yang dibuat maka semakin kecil nilai FK yang dihasilkan, sebaliknya semakin landai sudut lereng yang digunakan maka semakain aman FK lereng yang dihasilkan atau lereng dalam keadaan aman, sesuai klasifikasi Bowles (1984) FK aman berada pada nilai $\geq 1,25$. Jika nilai FK tidak mencapai $\geq 1,25$, maka kemungkinan kelongsoran akan masuk dalam kateogori pernah terjadi atau sering terjadi.

\subsection{Summary Laboratory}

Pengeboran geoteknik dilakukan untuk mengetahui stratigrafi di bawah permukaan bumi, jenis, serta kondisi batuan di daerah penelitian. Hasil dari Pengeboran geoteknik dilakukan untuk mendapatkan sampel batuan. Sampel selanjutnya diuji untuk mendapatkan nilai sifat fisik dan sifat mekanik batuan di laboratorium Mekanika Tanah PT Bukit Asam, Tbk. Rekapitulasi dari pengujian 
laboratorium disebut sebagai data summary laboratorium.

Pengujian sifat fisik diantaranya specific gravity, water content, bobot isi, void ratio, dan porositas. Pengujain sifat mekanik meliputi kuat geser (direct shear strength), kuat tekan triaksial, dan kuat tekan uniaksial (UCS). Kuat geser dan kuat tekan triaksial terjadi pada 2, kondisi, yaitu peak dan residual.

\subsection{Parameter Sifat Fisik dan Sifat Mekanik Batuan}

Berdasarkan hasil pengolahan data parameter yang telah diperoleh dari perhitungan statistika. Data parameter geoteknik pada area penambangan Banko Barat yang diklasifikasikan berdasarkan Lapisan batuan. Lapisan terdiri dari overburden, seam batubara, interburden dan lower C. Hasil pengujian memuat berupa kohesi, bobot isi batuan, dan sudut geser dalam yang diperoleh dari direct shear dan triaxial. Hasil Pengujian tersebut berupa nilai minimal, nilai maksimal, rata-rata, dan nilai tengah dalam bentuk persen. Nilai yang menjadi material properties sebagai untuk menginterpretasikan hasil nilai faktor keamanan.

Nilai triaxial dan direct shear yang digunakan adalah kelompok residual. Residual adalah tekanan geser yang dicapai setelah kuat geser puncak terlampaui. Nilai parameter hasil pengujian di laboratorium yang digunakan mewakili kondisi aktual dilapangan, sehingga nilai parameter digunakan untuk mendapatkan gambaran kondisi lapangan yang sebenaranya. Beberapa kondisi yang kurang mendukung seperti halnya menyebabkan hasil pengujian di laboraorium tidak sesuai dengan kondisi real yang ada di lapangan disehingga harus dilakukan back analysis. Memperoleh nilai parameter yang mendekati dengan kondisi real merupakan tujuan dari simulasi lereng yang dilakukan menjadi semakin akurat. Parameter tersebut dapat dilihat pada tabel 4.1.
Tabel 4.1 Parameter Sifat Fisik dan Mekanik Batuan Hasil Statistik Summary Laboratory Mekanik Daerah Banko Barat

\begin{tabular}{|l|l|l|l|l|}
\hline No. & Lapisan & $\begin{array}{l}\text { Bobot } \\
\text { isi } \\
\text { Batuan } \\
\left(\gamma_{\text {wet }}\right) \\
\left(\mathrm{kN} / \mathrm{m}^{3)}\right.\end{array}$ & $\begin{array}{l}\text { Sudut } \\
\text { Geser } \\
\text { Dalam } \\
\text { Batuan } \\
(\varphi) \\
\left({ }^{\mathrm{o}}\right)\end{array}$ & $\begin{array}{l}\text { Kohesi } \\
\text { Batuan } \\
(\mathrm{c}) \\
(\mathrm{kPa})\end{array}$ \\
\hline 1 & Overburden & 20,41 & 24,33 & 102,77 \\
\hline 2 & Seam A1 & 12,07 & 11,73 & 103,69 \\
\hline 3 & $\begin{array}{l}\text { Interburden } \\
\text { A1-A2 }\end{array}$ & 20,44 & 16,83 & 87,35 \\
\hline 4. & Seam A2 & 11,98 & 16,22 & 189,80 \\
\hline 5 & $\begin{array}{l}\text { Interburden } \\
\text { A2-B1 }\end{array}$ & 20,43 & 22,86 & 167,44 \\
\hline 6 & Seam B1 & 12,10 & 24,18 & 180,70 \\
\hline 7 & $\begin{array}{l}\text { Interburden } \\
\text { B1-B2 }\end{array}$ & 20,92 & 14,93 & 71,80 \\
\hline 8 & Seam B2 & 15,29 & 15,14 & 100,18 \\
\hline 9 & $\begin{array}{l}\text { Interburden } \\
\text { B2-C }\end{array}$ & 21,24 & 25,60 & 112,25 \\
\hline 10 & Seam C & 11,86 & 22,85 & 152,98 \\
\hline 11 & Lower $C$ & 21,06 & 61,05 & 26,44 \\
\hline
\end{tabular}

\subsection{Analisis Lereng Keseluruhan (Overall} Slope)

Dalam perhitungan faktor keamanan lereng dilakukan beberapa pendekatanpendekatan sebagai berikut :

1) Masing-masing material mempunyai nilai density, kohesi, dan sudut geser dalam yang kemudian di input kedalam tiap-tiap lapisan yang berbeda.

2) Tinggi muka airtanah diasumsikan berada $10 \mathrm{~m}$ dibawah permukaan tanah.

3) Memasukkan nilai akselerasi seismik sebesar 0,02 g (untuk daerah yang tidak diadakan peledakan).

4) Perhitungan faktor keamanan menggunakan metode Morgenstren-Price.

5) Faktor Keamanan $\geq 1,25$ (menurut Bowles, 1984).

Berdasarkan analisa kestabilan lereng menggunakan software Geostudio Slope/W 2018, maka didapatkan nilai optimasi faktor keamanan untuk lereng keseluruhan (overall slope) sisi high wall dari lapisan overburden hingga interburden A2-B1 dengan beberapa desain percobaan yang telah di buat dimulai dari situasi bulan Februari 2019 dengan jarak crest, yaitu 131,35 m dari sungai hingga 
pembuatan crest yang berjarak $\pm 50 \mathrm{~m}$ dari sungai sesuai dengan Peraturan Pemerintah Nomor 38 Tahun 2011.

\subsubsection{Overall Slope Desain Percobaan \\ Pertama}

Pada desain overall slope yang pertama dibuat tinggi lereng keseluruhan keseluruhan dari crest hingga toe sekitar $56 \mathrm{~m}$ dengan elevasi toe yang berada pada -10 meter di bawah permukaan laut dan elevasi crest yang berada pada +46 meter di atas permukaan laut. Kondisi geomteri lereng tunggal dibuat memiliki tinggi $8 \mathrm{~m}$ dan berm (lebar jenjang) $10 \mathrm{~m}$ dengan sudut kemiringan single slope $45^{\circ}$. Tinggi dan berm dibuat seragam dari crest hingga ke toe. Jarak crest yang dibuat pada desain pertama dari crest yang ada pada situasi bulan Februari 2019 maju ke arah sungai sekitar $\pm 48 \mathrm{~m}$ dan crest yang dibuat pada desain pertama ke sungai berjarak berkisar \pm $83 \mathrm{~m}$.

Lereng keseluruhan yang dibuat berdasarkan desain percobaan pertama menggunakan 7 bench dengan sudut overall slope yang didapat sebesar $25,77^{\circ}$. Dapat dilihat pada daerah yang diberi tanda kotak (Gambar 4.5) merupakan daerah yang akan dilakukannya penggalian untuk mendapatkan material seam batubara. Hasil dari penggalian pada desain percobaan pertama akan didapati seam A1 dan seam A2 sampai pada elevasi -10 mdpl.

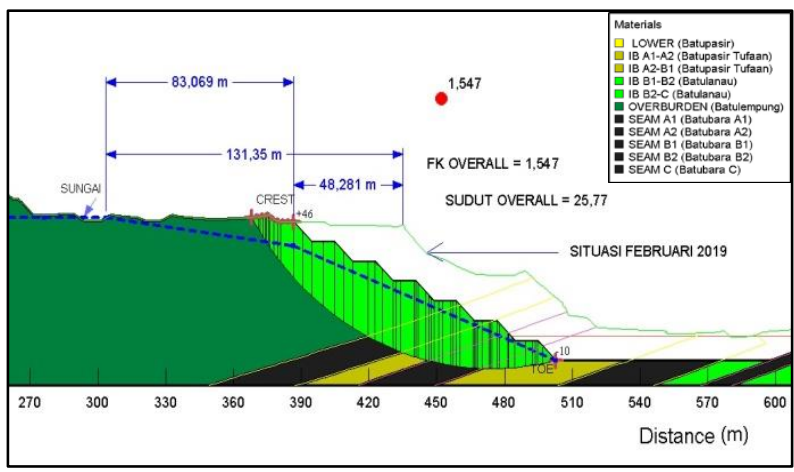

Gambar 4.5 Desain Percobaan Pertama Daerah Pengamatan Sisi High Wall

Hasil perhitungan dengan menggunakan software Geostudio Slope/W 2018 nilai faktor keamanan yang didapatkan, yaitu FK = 1,547 (Gambar 4.5). Dari nilai FK yang telah diketahui dapat di kategorikan lereng dalam keadaan aman.

\subsubsection{Overall Slope Desain Percobaan Kedua}

Pada desain overall slope yang kedua dibuat tinggi lereng keseluruhan keseluruhan dari crest hingga toe sekitar $58,5 \mathrm{~m}$ dengan elevasi toe yang berada pada -10 meter di bawah permukaan laut dan elevasi crest yang berada pada $+48,5$ meter di atas permukaan laut. Kondisi geomteri lereng tunggal dibuat memiliki tinggi $8 \mathrm{~m}$ dan berm (lebar jenjang) $10 \mathrm{~m}$ dengan sudut kemiringan single slope $45^{\circ}$. Tinggi dan berm tetap dibuat seragam dari crest hingga ke toe. Jarak crest yang dibuat pada desain kedua dari crest yang ada pada situasi bulan Februari 2019 maju ke arah sungai sekitar $\pm 60 \mathrm{~m}$ dan crest yang dibuat pada desain kedua ke sungai berjarak berkisar $\pm 70 \mathrm{~m}$.

Lereng keseluruhan yang dibuat berdasarkan desain percobaan kedua menggunakan 7 bench dengan sudut overall slope yang didapat sebesar $26,17^{\circ}$. Dapat dilihat pada daerah yang diberi tanda kotak (Gambar 4.6) merupakan daerah yang akan dilakukannya penggalian untuk mendapatkan material seam batubara. Hasil dari penggalian pada desain percobaan kedua akan didapati seam A1 dan seam A2 sampai pada elevasi -10 mdpl lebih banyak dari desain pertama.

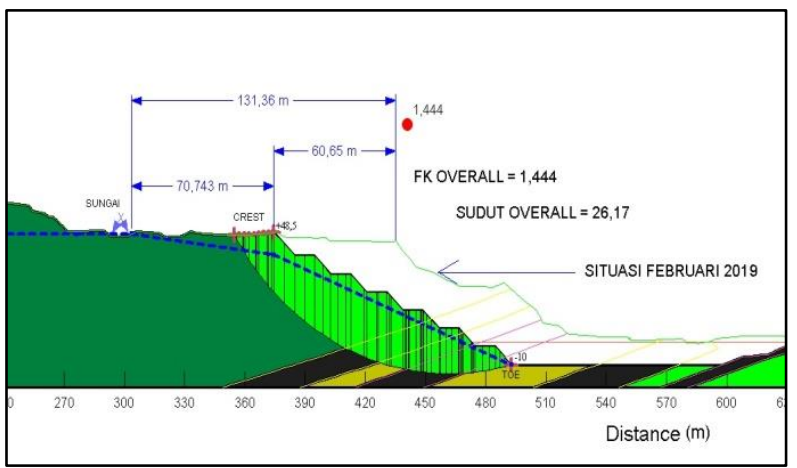

Gambar 4.6 Desain Percobaan Kedua Daerah Pengamatan Sisi High Wall

Hasil perhitungan dengan menggunakan software Geostudio Slope/W 2018 nilai faktor keamanan yang didapatkan, yaitu FK = 1,444 (Gambar 4.6). Dari nilai FK 
yang telah diketahui dapat dikategorikan bahwa lereng masih dalam keadaan aman.

\subsubsection{Overall Slope Desain Percobaan Ketiga}

Pada desain overall slope yang ketiga dibuat tinggi lereng keseluruhan keseluruhan dari crest hingga toe sekitar $74 \mathrm{~m}$ dengan elevasi toe yang berada pada -26 meter di bawah permukaan laut dan elevasi crest yang berada pada +48 meter di atas permukaan laut. Kondisi geometri lereng tunggal dibuat memiliki tinggi $8 \mathrm{~m}$ dan berm (lebar jenjang) $10 \mathrm{~m}$ dengan sudut kemiringan single slope $45^{\circ}$. Tinggi dan berm tetap dibuat seragam dari crest hingga ke toe. Jarak crest yang dibuat pada desain ketiga dari crest yang ada pada situasi bulan Februari 2019 maju ke arah sungai sekitar $\pm 65 \mathrm{~m}$ dan crest yang dibuat pada desain ketiga ke sungai berjarak berkisar $+66 \mathrm{~m}$.

Dapat dilihat pada daerah yang diberi tanda kotak (Gambar 4.7) merupakan daerah yang akan dilakukannya penggalian untuk mendapatkan material seam batubara. Hasil dari penggalian pada desain percobaan ketiga akan didapati seam A1, seam A2, dan seam B1 sampai pada elevasi -26 mdpl.

$$
\text { Hasil perhitungan dengan }
$$

menggunakan software Geostudio Slope/W 2018 nilai faktor keamanan yang didapatkan, yaitu FK = 1,365 (Gambar 4.7). Dari nilai FK yang telah diketahui dapat dikategorikan lereng masih dalam keadaan aman.

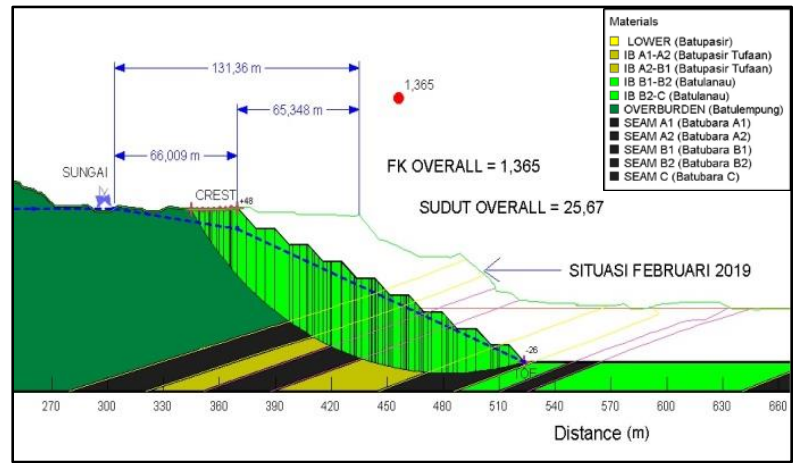

Gambar 4.7 Desain Percobaan Ketiga Daerah Pengamatan Sisi High Wall

\subsubsection{Overall Slope Desain Percobaan Keempat}

Pada desain overall slope yang keempat dibuat tinggi lereng keseluruhan dari crest hingga toe sekitar $73 \mathrm{~m}$ dengan elevasi toe yang berada pada -26 meter di bawah permukaan laut dan elevasi crest yang berada pada +47 meter di atas permukaan laut. Kondisi geomteri lereng tunggal dibuat memiliki tinggi $8 \mathrm{~m}$ dan berm (lebar jenjang) $10 \mathrm{~m}$ dengan sudut kemiringan single slope $53^{\circ}$. Pada desain keempat dibuat sedikit lebih terjal atau curam dari desain sebelumnya untuk memaksimalkan proses penambangan agar produksi pada seam batubara yang di ambil lebih banyak, bench yang dibuat masih sama banyaknya seperti desain sebelumnya, yaitu sebanyak 9 bench. Tinggi dan berm tetap dibuat seragam dari crest hingga ke toe. Jarak crest yang dibuat pada desain keempat dari crest yang ada pada situasi bulan Februari 2019 maju ke arah sungai sekitar $\pm 80 \mathrm{~m}$, dan crest yang dibuat pada desain keempat ke sungai berjarak berkisar $\pm 50 \mathrm{~m}$.

Dapat dilihat pada daerah yang diberi tanda kotak (Gambar 4.8) merupakan daerah yang akan dilakukannya penggalian untuk mendapatkan material seam batubara. Hasil dari penggalian pada desain percobaan keempat akan didapati seam A1, seam A2, dan seam B1 sampai pada elevasi $-26 \mathrm{mdpl}$ akan tetapi perolehan seam batubara lebih banyak dari percobaan ketiga.

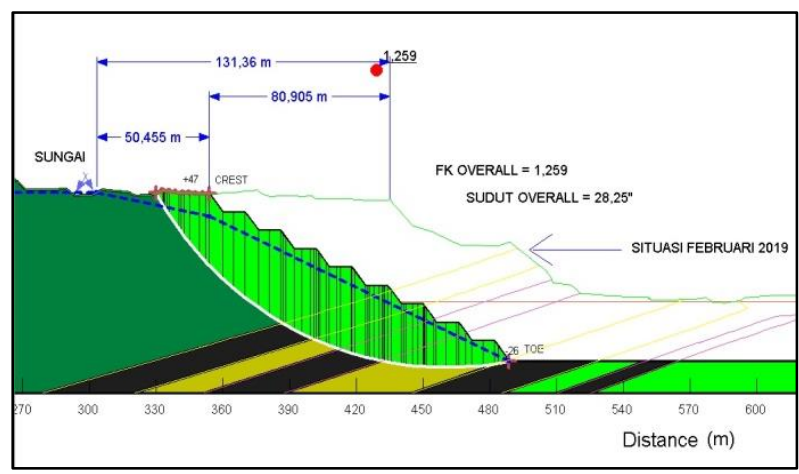

Gambar 4.8 Desain Percobaan Keempat Daerah Pengamatan Sisi High Wall

Hasil perhitungan dengan menggunakan software Geostudio Slope/W 2018 nilai faktor keamanan yang didapatkan, yaitu FK = 1,259 (Gambar 4.8). Dari nilai FK 
yang telah diketahui dapat dikategorikan lereng masih dalam keadaan aman.

\subsubsection{Overall Slope Desain Percobaan Kelima}

Pada beberapa percobaan pembuatan desain lereng untuk mendapatkan nilai FK yang optimum didapatkan desain dengan FK yang tepat sebesar 1,25 (Gambar 4.9) artinya lereng dalam keadaan stabil dengan muka airtanah berada pada $-10 \mathrm{~m}$ di bawah permukaan laut dengan jarak dari crest ke sempadan sungai sekitar $26 \mathrm{~m}$. Pengoptimalan FK pada lereng dimaksudkan agar proses penambangan dapat mendapatkan produksi pada seam batubara sebanyaknya dengan tetap memperhatikan faktor keamanan lereng yang ada. Akan tetapi, dengan desain yang dibuat tersebut didapatkan jarak crest yang tidak memenuhi persyaratan batas maksimal jarak yang harus dibuat sesuai Peraturan Pemerintah Nomor 38 Tahun 2011, maka tidak direkomendasikan untuk dilakukannya penambangan dengan desain tersebut.

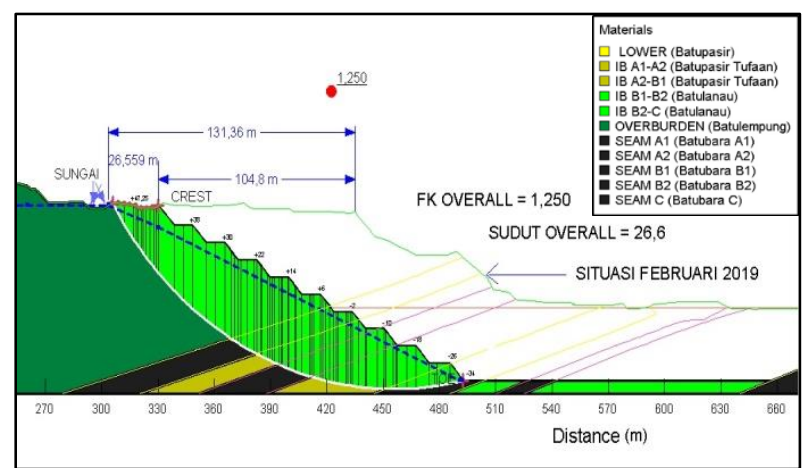

Gambar 4.9 Desain Percobaan Kelima Daerah Pengamatan Sisi High Wall

Peraturan Pemerintah Republik Indonesia Nomor 38 Tahun 2011 Tentang Sungai pada pasa 10 menjelaskan sebagai berikut :

1) Sungai tidak bertanggul di luar kawasan pekotaan sebagaimana dimaksud dalam pasal 8 ayat (2) huruf $b$ terdiri atas :

a) Sungai besar dengan luas DAS lebih besar dari $500 \mathrm{~km}^{2}$ (lima ratus kilometer persegi); dan

b) Sungai kecil dengan luas DAS kurang dari atau sama dengan $500 \mathrm{~km}^{2}$ (lima ratus kilometer persegi).
2) Garis sempadan sungai tidak bertanggul di luar kawasan perkotaan sebagaimana dimaksud pada ayat (1) huruf a ditentukan paling sedikit berjarak $100 \mathrm{~m}$ (seratus meter) dari tepi dan kanan palung sungai sepanjang alur sungai.

3) Garis sempadan sungai kecil tidak bertanggul di luar kawasan perkotaan sebagaimana dimaksud pada ayat (1) huruf b ditentukan paling sedikit $50 \mathrm{~m}$ (lima puluh meter) dari tepi dan kanan sungai sepanjang alur sungai.

Dari bentuk dan luas sungai yang di ketahui berdasarkan hasil pengamatan di lapangan maka sungai yang berada di lokasi pengamatan dikategorikan masuk kedalam luasan sungai yang kecil atau kurang dari 500 $\mathrm{km}^{2}$. Maka jarak yang di tentukan berdasarkan Peraturan Pemerintah Nomor 38 Tentang sungai, yaitu terdapat pada ayat 3 , sebagaimana disebutkan bahwa garis sempadan sungai tidak bertanggul berjarak 50 $\mathrm{m}$ dari desain crest yang harus dibuat.

Dari beberapa percobaan yang telah dilakukan didapatkan beberapa faktor keamanan lereng yang berbeda pada tiap desain yang dibuat mulai dari $\mathrm{FK}=1,547$ sampai $\mathrm{FK}=1,250$ dan dengan jarak crest ke sempadan sungai yang berdeba pula mulai dari $83 \mathrm{~m}$ sampai $26 \mathrm{~m}$. Sesuai dengan Peraturan Pemerintah Republik Indonesia Nomor 38 Tahun 2011 Tentang Sungai maka berdasarkan percobaan pembuatan desain lereng yang telah dilakukan didapatkan hasil desain optimum yang disarankan sesuai dengan persyaratan dalam pembuatan desain lereng yang aman yaitu pada desain percobaan keempat dengan $\mathrm{FK}=1,259$ yang berarti lereng masuk dalam kategori aman, dimana jarak crest ke sempadan sungai sekitar $\pm 50 \mathrm{~m}$ dengan tinggi lereng keseluruhan dari toe sampai crest sekitar $74 \mathrm{~m}$ dan elevasi toe berada pada $-26 \mathrm{~m}$ di bawah permukaan laut yang berarti memungkinkan untuk dilakukannya penggalian yang lebih dalam untuk memperoleh seam batubara, dan perolehan seam batubara yang didapatkan juga lebih banyak dibandingkan dari desain percobaan pertama, kedua, maupun ketiga dengan 
kedalaman pada elevasi $-26 \mathrm{~m}$ di bawah permukaan laut.

\subsubsection{Overall Slope Desain Percobaan Keenam}

Pada desain overall slope yang keenam dibuat tinggi lereng keseluruhan keseluruhan dari crest hingga toe sekitar $80 \mathrm{~m}$ dengan elevasi toe yang berada pada -33 meter di bawah permukaan laut dan elevasi crest yang berada pada +47 meter di atas permukaan laut. Kondisi geomteri lereng tunggal dibuat memiliki tinggi $8 \mathrm{~m}$ dan berm (lebar jenjang) $10 \mathrm{~m}$ dengan sudut kemiringan single slope $45^{\circ}$. Tinggi dan berm tetap dibuat seragam dari crest hingga ke toe. Jarak crest yang dibuat pada desain keenam dari crest yang ada pada situasi bulan Februari 2019 maju ke arah sungai sekitar $\pm 80 \mathrm{~m}$ dan crest yang dibuat pada desain keenam ke sungai berjarak berkisar $\pm 50 \mathrm{~m}$.

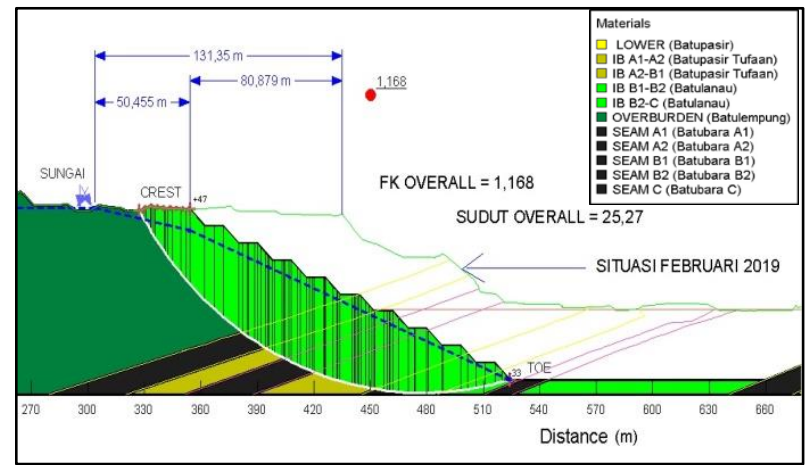

Gambar 4.10 Desain Percobaan Keenam Daerah Pengamatan Sisi High Wall

Lereng keseluruhan yang dibuat berdasarkan desain percobaan keenam menggunakan 10 bench dengan sudut overall slope yang didapat sebesar $25,27^{\circ}$ dan perbandingan sudut tiap single slope 1:1 untuk meminimasilisir terjadinya longsor, maka sudut dibuat tidak terlalu curam dan tidak juga dibuat terlalu landai agar seam batubara tetap dapat diperoleh secara maksimal dengan memperhatikan tingkat keamanan lereng yang dibuat. Hasil perhitungan dengan menggunakan software Geostudio Slope/W 2018 nilai faktor keamanan yang didapatkan, yaitu FK = 1,168 (Gambar 4.10). Dari nilai FK yang diketahui dapat dilihat bahwa FK di bawah 1,25 yang berarti lereng dalam keadaan kritis (tidak direkomendasikan).

\subsubsection{Overall Slope Desain Percobaan Ketujuh}

Pada desain overall slope yang ketujuh dibuat tinggi lereng keseluruhan keseluruhan dari crest hingga toe sekitar 97,25 m dengan elevasi toe yang berada pada $-49,75$ meter di bawah permukaan laut dan elevasi crest yang berada pada $+47,5$ meter di atas permukaan laut. Kondisi geomteri lereng tunggal dibuat memiliki tinggi $8 \mathrm{~m}$ dan berm (lebar jenjang) $10 \mathrm{~m}$ dengan sudut kemiringan single slope $53^{\circ}$. Tinggi dan berm tetap dibuat seragam dari crest hingga ke toe. Jarak crest yang dibuat pada desain ketujuh dari crest yang ada pada situasi bulan Februari 2019 maju ke arah sungai sekitar $\pm 104 \mathrm{~m}$ dan crest yang dibuat pada desain ketujuh ke sungai berjarak berkisar $\pm 26,5 \mathrm{~m}$.

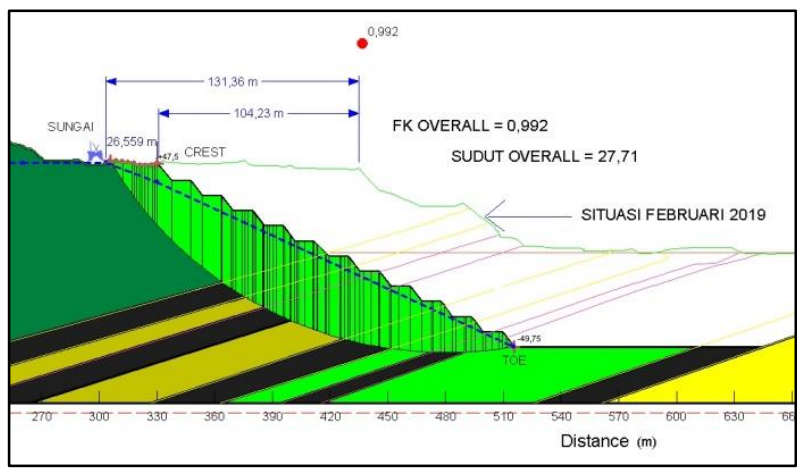

\section{Gambar 4.11 Desain Percobaan Ketujuh Daerah Pengamatan Sisi High Wall}

Lereng keseluruhan yang dibuat berdasarkan desain percobaan ketujuh menggunakan 12 bench dengan sudut overall slope yang didapat sebesar $27,71^{\circ}$ dan perbandingan sudut tiap single slope 1:1,3 untuk meminimasilisir terjadinya longsor, maka sudut dibuat tidak terlalu curam dan tidak juga dibuat terlalu landai agar seam batubara tetap dapat diperoleh secara maksimal dengan memperhatikan tingkat keamanan lereng yang dibuat. Hasil perhitungan dengan menggunakan software Geostudio Slope/W 2018 nilai faktor keamanan yang didapatkan, yaitu $\mathrm{FK}=0,992$ (Gambar 4.11). Dari nilai FK yang diketahui 
dapat dilihat bahwa FK di bawah 1 yang berarti lereng dalam keadaan labil (tidak direkomendasikan).

Tabel 4.2 Nilai Faktor Keamanan Lereng Overall Slope Desain Percobaan

\begin{tabular}{|c|c|c|c|c|c|c|c|c|}
\hline \multirow[b]{2}{*}{ 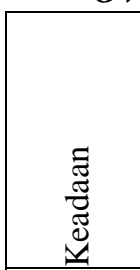 } & \multirow{2}{*}{ 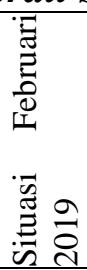 } & \multicolumn{7}{|c|}{ Desain Percobaan } \\
\hline & & 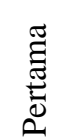 & 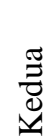 & 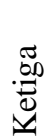 & 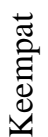 & 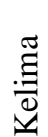 & 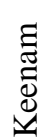 & 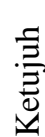 \\
\hline 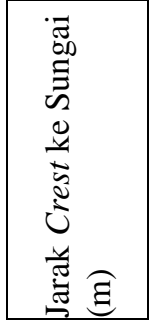 & $\begin{array}{l}\infty \\
\infty \\
\stackrel{m}{\pi}\end{array}$ & $\infty$ & $\hat{R}$ & 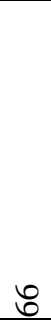 & $\stackrel{+}{\circ}$ & ñ & 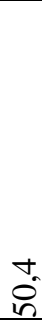 & n \\
\hline 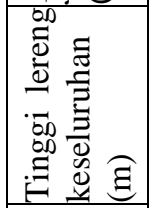 & $\frac{n}{7}$ & $\stackrel{\circ}{n}$ & $\begin{array}{l}n \\
\infty \\
n\end{array}$ & 寺 & $n$ & $\stackrel{2}{2}$ & $\infty$ & $\frac{n}{2}$ \\
\hline 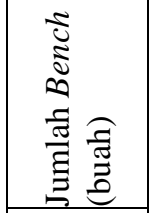 & $N$ & $r$ & $r$ & $a$ & $a$ & 으 & 으 & 드 \\
\hline 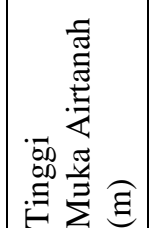 & 은 & $\stackrel{0}{1}$ & $\stackrel{0}{1}$ & 윽 & $\stackrel{0}{1}$ & 윽 & 음 & 음 \\
\hline 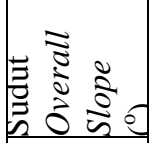 & $\begin{array}{l}n \\
i \\
\sim\end{array}$ & $\stackrel{\hat{N}}{\sim}$ & $\begin{array}{l}5 \\
6 \\
0\end{array}$ & $\begin{array}{l}\hat{\sigma} \\
\tilde{a} \\
i\end{array}$ & $\begin{array}{l}n \\
\infty \\
\infty \\
\text { N }\end{array}$ & $\begin{array}{l}0 \\
0 \\
\text { d }\end{array}$ & 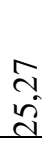 & $\vec{N}$ \\
\hline$\frac{v}{I}$ & $\begin{array}{l}\text { o } \\
8 \\
\text { i }\end{array}$ & 苟 & $\underset{-}{\stackrel{f}{f}}$ & ?2 & 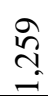 & $\begin{array}{l}\stackrel{0}{n} \\
\stackrel{2}{\approx}\end{array}$ & $\begin{array}{l}\infty \\
0 \\
=\end{array}$ & ๙ু \\
\hline
\end{tabular}

Dari gambar 4.12 dikatehui nilai FK yang didapat berdasarkan beberapa desain percobaan yang dibuat, yaitu mulai dari FK 2,096 sampai FK 0,992. Berdasarkan klasifikasi Bowles (1984), nilai FK lereng dibagi menjadi 3. Maka, untuk mempermudah membaca grafik di atas dibuat simbol yang mewakili nilai FK dengan menggunakan garis panah dengan warna yang berbeda. Garis hijau ke atas menunjukkan nilai $\mathrm{FK} \geq 1,25$ yang berarti lereng dalam keadaan aman, garis wana kuning di tengah menunjukkan nilai FK 1,071,25 yang berarti lereng dalam keadaan kritis, dan garis merah ke bawah menunjukkan nilai FK $<1,07$ yang berarti lereng dalam keadaan tidak aman/rawan longsor.

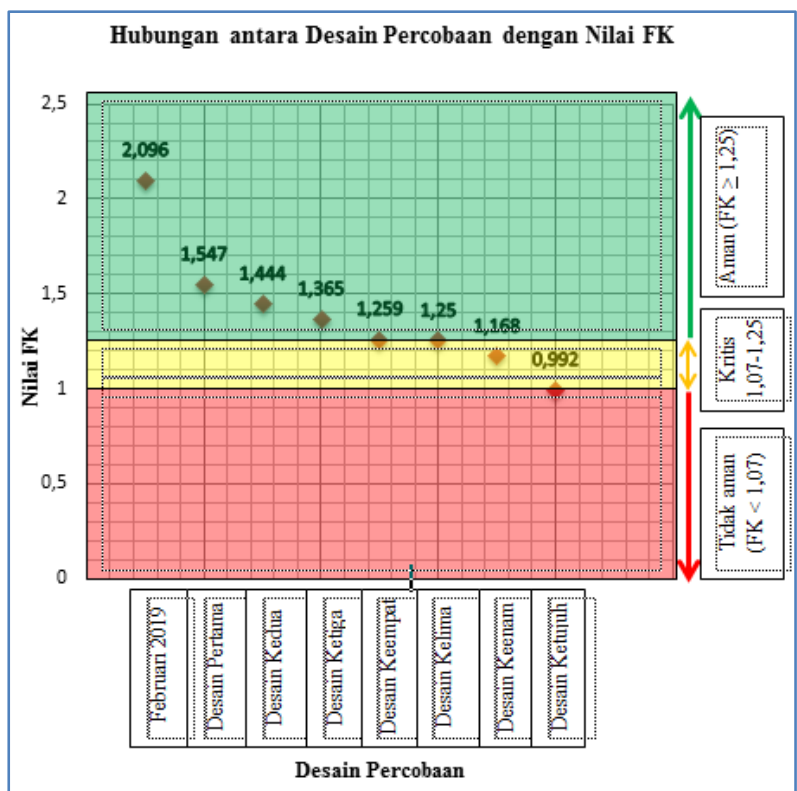

Gambar 4.12 Hubungan antara Desain Percobaan dengan Nilai FK

\section{KESIMPULAN DAN SARAN \\ 5.1 Kesimpulan}

Dari pembahasan tersebut, maka kesimpulan dari penelitian ini, yaitu :

1. Berdasarkan hasil analisis lereng situasi bulan Februari 2019 didapatkan nilai FK $=2,096$, yang berarti lereng masih dalam keadaan aman dan masih memungkinkan untuk dilakukan penambangan sampai batas optimum lereng aman yang disarankan, yaitu sebesar $\mathrm{FK}=1,25$.

2. Daerah Penelitian berada pada sisi high wall Tambang Banko Barat Pit 1 Utara yang menggunakan metode penambangan strip mine dimana penambangan mengikuti arah sebaran batubara dengan kondisi muka airtanah diasumsikan berada $-10 \mathrm{~m}$ di bawah permukaan tanah dengan beberapa lapisan yang tersusun pada lereng pengamatan dari crest sampai toe berupa material OB (overburden), seam batubara A1, interburden A1-A2, seam 
batubara A2, interburden A2-B1, dan seam Batubara B1, yang dibuat rencana desain lereng dengan memperhatikan sisi yang berdekatan dengan sungai sekitar \pm $131 \mathrm{~m}$, maka dibuat desain rencana dengan memperhatikan Peraturan Pemerintah Nomor 38 Tahun 2011 Tentang Sungai sebagai acuan yang menyebutkan bahwa jarak crest dengan sungai paling sedikit berjarak $50 \mathrm{~m}$ dari sempadan sungai. Hal tersebut juga dimaksudkan agar pada proses kegiatan penambangan tidak adanya bahaya yang akan terjadi nantinya akibat longsoran yang disebabkan aliran air yang terlalu dengan dengan permukaan kerja.

3. Nilai faktor keamanan desain percobaan.

a. Pada desain pertama, kedua, ketiga, dan keempat memiliki nilai faktor keamanan overall slope > 1,25 mulai dari $\mathrm{FK}=1,547$ sampai dengan $\mathrm{FK}=$ 1,259 berdasarkan percobaan yang telah dilakukan, berarti lereng dalam keadaan aman sesuai dengan kriteria Bowles (1984) dan sesuai dengan Peraturan Pemerintah Nomor 38 Tahun 2011 Tentang Sungai. Jarak crest yang dibuat dari sungai juga tergolong diperbolehkan untuk dijadikan desain rencana kerja yaitu mulai dari $83 \mathrm{~m}$ sampai jarak paling sedikit yang ditetapkan, maka desain percobaan pertama, kedua, ketiga, dan keempat bisa dijadkan sebagai desain rekomendasi Rencana Kerja Anggaran Perusahaan (RKAP).

b. Terdapat percobaan pembuatan desain lereng dengan $\mathrm{FK}$ optimum $=1,25$ pada percobaan desain kelima yang berarti lereng dalam keadaan stabil, akan tetapi desain tersebut tidak disarankan untuk dijadikan rencana kerja dikarenakan bertentangan dengan PP No 38 Tahun 2011 yang berisi bahwa jarak crest dengan sempadan sungai paling sedikit $50 \mathrm{~m}$, sedangkan desain tersebut memiliki jarak dari crest ke sempadan sungai sekitar \pm 26 $m$. Pada percobaan desain keenam dan ketujuh didapatkan FK dibawah 1,25 yang berarti lereng berada dalam keadaan kritis atau juga lereng dalam keadaan tidak aman, maka tidak direkomendasikan untuk dijadikan desain rencana kerja.

\subsection{Saran}

Saran yang dapat diberikan dari penelitian ini, yaitu :

1. Desain lereng aktual yang ada di lapangan sebaiknya disesuaikan dengan desain Rencana Kerja dan Anggaran Perusahaan untuk meminimalisir suatu waktu terjadinya bahaya akibat longsor yang terjadi akibat lereng yang tidak stabil.

2. Dibutuhkannya perhitungan kondisi muka airtanah yang lebih mendetail pada daerah penelitian baik pada musim hujan maupun musim kemarau agar didapatkan nilai faktor keamanan lereng yang lebih akurat.

3. Pengujian laboratorium terhadap sampel dari lapangan sebaiknya dilakukan dengan teliti dengan banyak titik uji sampel.

4. Diharapkan untuk penelitian selanjutnya agar dapat diketahui nilai SR dan volume material yang didapatkan dari pengupasan material overburden dan seam batubara dari hasil desain yang telah dibuat.

\section{DAFTAR PUSTAKA}

Bieniawski, Z.T. 1989. Engineering Rock Mass Classification. New York: Wiley Interscience Publication.

Bowles, J. E. 1984. Sifat-Sifat Fisis dan Geoteknis Tanah (Mekanika Tanah). Edisi Kedua. Erlangga. Jakarta.

Bowles, J. E. 1993. Physical and Geotechnical Properties of Soil: Second Edition. New York : USA McGraw-Hill.

Cheng, Y. M., and C. K. Lau. 2008. Slope Stability Analysis and Stabilization, New Methods and Insight. London. Routledge.

De Coster, G. L. 1974. The Geology of the Central and South Sumatra. Indonesian 
Petroleum Association 3rd Annual Convertion.

Deere. 1988. The Rock Quality Index in Practice. Rock Classification System for Engineering Purposes. ASTM STP 984 Kirkaldie Edition. New York.

Edelbro, C. 2003. Rock Mass Strength. Department of Civil Engineering Division of Rock Mechanics. Lulea University of Technology.

Fookes, P. G. And Dennes B., 1969. Observational Studies on Fissure Patterns in Crestaceous Sediments of South East England. Geotechnique.

Gabrielsen, R. H. 1990. Characteristics of Joints and Faults. Proceesdings of the International Symposium on Rock Joints. Loen. Norway. N. Bartonand. Stephansson (eds). Balkema. Rotterdam.

Hoek, E and Bray, J.W. 1981. Rock Slope Engineering. London : Institution of Mining and Metallurgy.

Koesoemadinata, R. P. Dan Hardjono. 1978. Tertiary Coal Basins of Indonesia. Prepared for the $10^{\text {th }}$ Ann. Of CCOP. Geology Survey of Indonesia

Krahn, J. 2004. Stability Modelling with Slope/w-An Engineering Methodology First edition. Canada : Geo-Slope International, Ltd.

Made Astawa Rai. 1993. Kemantapan Lereng Batuan. Kursus Pengawas Tambang. Bandung.

Palmstrom, A. 2001. Measurement And Characterization Of Rock Mass Jointing. Chapter 2 of the book: In-Situ Characterization of Rocks. Övre Smestad vei.

Pemerintah Indonesia. 2011. Peraturan Pemerintah Republik Indonesia Nomor 38 Tahun 2011 Tentang Sungai.

Priest, S. D. 1993. Discontinuity Analysis for
Rock Engineering. Chapman \& Hall. ISBN 0 412476002.

Pulunggono, A. 1983. Sistem Sesar Utama dan Pembentukan Cekungan Palembang (Main Fault System and the Formation of the Palembang Arc). Doctoral Dissertation. Bandung Institute of Technology.

Swan, Colby C. And Seo, Y. K. 1999. Slope Stability Analysis Using Finite Element Technique.13 $3^{\text {th }}$ lowa ASCE Geotechnical Conference. Williamsburgh, lowa.

Ward, T. J. 1976. Factor of Safety Approach to Landside Potential Delineation. Dissertation. Department of Civil Engineering. Colorado State. Forth Collins. Colorado.

Wesley. 1977. Mekanika Tanah. Badan Penerbit Pekerjaan Umum. 
P-ISSN: 2089-5925 E-ISSN: 2621-9328

Antrant

Jurnal Teknik Patra Akademika

PA

A KaAemiKa

Volume 09 No 01 Juli 2018 